\title{
PERANCANGAN SISTEM INFORMASI AKUNTANSI PENGENDALIAN PERSEDIAAN BBM KAPAL LAUT DENGAN MENERAPKAN METODE EOQ
}

Kasih Purwantini ${ }^{1}$, Eni Endaryati ${ }^{2}$, Iwan Koerniawan ${ }^{3}$

${ }^{1,2}$ Universitas Sains dan Teknologi Komputer

Jalan majapahit No605 Semarang, kasih@stekom.ac.id; enyendaryati@stekom.ac.id, iwan@stekom.ac.id

\begin{tabular}{|c|c|}
\hline ARTICLE INFO & ABSTRACT \\
\hline $\begin{array}{l}\text { Article history: } \\
\text { Received } 30 \text { September } 2021 \\
\text { Received in revised form } 2 \text { Nov } 2021 \\
\text { Accepted } 10 \text { Nov } 2021 \\
\text { Available online } 12 \text { Des } 2021\end{array}$ & $\begin{array}{l}\text { This study aims to develop a fuel inventory control } \\
\text { system so that it can facilitate monitoring the } \\
\text { volume of fuel stock from each bunker ship and can } \\
\text { be reported at any time, so that the leadership can } \\
\text { estimate the addition of fuel orders to PT. Pertamina } \\
\text { for each bunker ship that is adjusted to the incoming } \\
\text { fuel request order. If there is a sudden fuel order by } \\
\text { the customer, the company can still serve the } \\
\text { customer well, so that the fuel stock can be } \\
\text { controlled and can be monitored properly at any } \\
\text { time. } \\
\text { The research method used in the information system } \\
\text { monitoring the pump fabrication process is Research } \\
\text { and Development (R\&D) in this study only until the } \\
\text { 6th (sixth) stage and produces the final product in } \\
\text { the form of a prototype, so it does not reach the } \\
\text { product implementation stage. The six steps are } \\
\text { Research and information collecting, Planning, } \\
\text { Develop preliminary form of product, Preliminary } \\
\text { field testing, Main product revision and Main field } \\
\text { testing. This application is made using Macromedia } \\
\text { Dream Weaver and MySQL database. }\end{array}$ \\
\hline
\end{tabular}

Keywords: Information systems, Control, Inventory, Accounting

\section{Pendahuluan}

Seiring dengan perkembangan teknologi informasi dan komunikasi yang sangat cepat pada saat ini. Hampir semua perusahaan besar, menengah dan kecil telah memanfaatkan teknologi informasi dengan menggunakan perangkat komputer dalam lingkup kerjanya. Teknologi informasi saat ini dapat membantu segala usaha bisnis dalam meningkatkan efisiensi dan kinerja perusahaan dengan sangat baik. Disamping itu dengan adanya penyajian informasi yang baik akan mampu digunakan untuk pengambilan keputusan oleh pihak manajemen dengan tepat. Penerapan sistem informasi dengan menggunakan teknologi internet sebagai sarana penyampaian informasi secara cepat sudah tidak terkendala dengan jarak yang jauh atau tempat yang berbeda, sehingga telah banyak digunakan dalam kegiatan bisnis diataranya penjualan dan pemesanan barang maupun jasa secara online, demikian juga sebagai sarana pemantauan persediaan dan distribusi barang. 
Semakin berkembang suatu perusahaan, maka proses bisnis dan transaksi yang dilakukan akan semakin banyak sehingga data yang terkumpul akan semakin besar. Oleh karena itu data harus diorganisir dan bisa dikelola dengan sebaik mungkin sehingga akan menjadi suatu informasi yang bermanfat. Untuk itu dibutuhkan adanya sistem informasi yang bertujuan untuk mengemas dan mengelola data yang ada menjadi informasi-informasi yang bisa digunakan dalam kegiatan operasional sehari-hari maupun dalam pengambilan keputusan. Melalui sistem informasi yang baik, diharapkan mampu menyajikan informasi yang lebih efektif, efisien, cepat dan lengkap serta mampu menyimpan data-data dalam jumlah yang besar, dan mudah untuk medapatkan datadata yang dibutuhkan.

BBM (Bahan Bakar Minyak) merupakan sumber daya alam yang dimiliki oleh bangsa Indonesia. Pemanfaatan dan pemakaian BBM tersebut harus dengan bijak. Kebutuhan masyarakat ataupun perusahaan akan BBM juga sudah begitu besar terutama untuk transportasi, baik untuk transportasi darat, laut dan udara. Keterlambatan pasokan BBM akan sangat berdampak besar pada aktivitas operasional masyarakat atau perusahaan. Banyak perusahaan yang bergerak dalam bidang pendistribusian BBM telah memanfaatkan teknologi informasi pemantauan persediaan BBM-nya. PT. Tri Karya Wiguna yang beralamat di Jl. Sendang Indah Raya No. 1 Semarang, merupakan agen dari PT. Pertamina (Persero) yang mendistribusikan BBM untuk kapal-kapal laut, seperti HSD (Solar), MFO (Minyak Bakar) dan MDF (Minyak Diesel). Perusahaan ini memiliki 2 (dua) armada kapal bernama SPOB Aans dan MT. Alfatah Fatahillah yang digunakan untuk proses pengisian BBM di kapal-kapal laut baik pengisian di tengah laut maupun di dermaga. Daerah operasionalnya meliputi pelabuhan-pelabuhan di wilayah Kota Tegal, Kendal, Semarang, Rembang, Jepara dan sekitarnya. Pelanggannya mencapai sekitar 150 perusahaan yang tersebar di beberapa kota di Indonesia, bahkan beberapa dari perusahaan pelayaran di luar negeri.

Berikut ini adalah data stok BBM PT. Tri Karya Wiguna selama 3 (tiga) bulan pada tahun 2020 :

Tabel 1. Data Stok BBM

\begin{tabular}{|l|l|c|c|c|c|c|c|l|}
\hline $\begin{array}{l}\text { Nama } \\
\text { Kapal }\end{array}$ & \multicolumn{2}{|l}{ Kapal SPOB Aans } \\
\hline Periode & Stok Awal & $\begin{array}{r}\text { BBM } \\
\text { Masuk }\end{array}$ & $\begin{array}{c}\text { BBM } \\
\text { Keluar }\end{array}$ & $\begin{array}{c}\text { Stok } \\
\text { Akhir }\end{array}$ & $\begin{array}{c}\text { Stok } \\
\text { Awal }\end{array}$ & $\begin{array}{c}\text { BBM } \\
\text { Masuk }\end{array}$ & BBM Keluar & Stok Akhir \\
\hline Jan & 35.000 & 1.345 .000 & 1.289 .000 & 91.000 & 41.000 & 1.430 .000 & 1.299 .000 & 172.000 \\
\hline Peb & 91.000 & 998.000 & 1.004 .000 & 85.000 & 172.000 & 788.000 & 855.000 & 105.000 \\
\hline Mar & 85.000 & 1.033 .000 & 1.052 .000 & 66.000 & 105.000 & 1.050 .000 & 1.111 .000 & 44.000 \\
\hline
\end{tabular}

Sumber data : PT. Tri Karya Wiguna - Semarang

Sistem kerja yang digunakan PT. Tri Karya Wiguna masih terdapat beberapa masalah, antara lain belum terpantaunya persediaan BBM dengan baik karena selama ini pendataan dan pemrosesan data masih menggunakan sistem semi komputerisasi dengan Microsoft Excel, sehingga sering mengakibatkan keterlambatan penyampaian laporan penjualan maupun stok BBM kepada pimpinan, karena harus merekap data yang ada pada Microsoft Excel. Kadangkala proses bunker BBM (pengisian BBM ke Kapal Laut) tidak terlaksana sesuai dengan jadwal waktu yang telah ditentukan, yang diakibatkan karena adanya cuaca buruk atau kerusakan mesin

JURNAL ILMIAH KOMPUTERISASI AKUNTANSI Vol. 14, No. 2, Desember 2021 : $256-264$ 
kapal, sehingga jumlah BBM yang seharusnya sudah terjadwal untuk didistribusikan mengalami keterlambatan. Hal seperti ini akan berpengaruh pada pengelolaan stok BBM, sehingga jika kejadiannya diluar jam kerja, maka tidak bisa dilaporkan langsung ke kantor, dan akibatnya stok BBM yang riil tidak bisa terpantau dengan baik. Proses pembelian BBM ke PT. Pertamina (Persero) ataupun PT. Pertamina Patra Niaga, memerlukan waktu yang tidak cepat karena harus menunggu armada mobil tanki yang kosong untuk proses pengisiannya ke kapal di dermaga. Sering kali ada pemesanan BBM yang dilakukan mendadak oleh pelanggan melalui mesin facsimile ataupun pembelian langsung dari kapal pelanggan, tapi pada saat itu stok BBM di kapal tidak mencukupi atau bahkan habis, akibatnya permintaan pengisian BBM ke kapal pelanggan tidak dapat dilayani atau tertunda.

Dengan latar belakang yang diuraikan diatas, maka perlu solusi untuk mengatasi masalah yang ada pada PT. Tri Karya Wiguna, yaitu mengembangkan suatu sistem informasi pengendalian persediaan BBM berbasis web. Melalui sistem yang baru ini diharapkan dapat mempermudah pemantauan volume stok BBM dari setiap kapal bunker dan bisa dilaporkan pada setiap saat, sehingga pimpinan bisa memperkirakaan penambahan order BBM ke PT. Pertamina untuk masing-masing kapal bunker yang disesuaikan dengan order permintaan BBM yang masuk. Jika terjadi ada pemesanan BBM yang mendadak oleh pelanggan, perusahaan masih dapat melayani pelanggan dengan baik, sehingga stok BBM dapat terkendali dan dapat dipantau dengan baik pada setiap saat. Disamping itu dengan adanya sistem yang baru ini, penyajian laporan penjualan dan persediaan BBM kepada pimpinan bisa dilakukan dengan cepat, karena informasi tersebut sudah siap dan up to date sehingga menjadi informasi yang sangat penting bagi pimpinan dalam pengambilan keputusan

\section{Tinjauan Pustaka}

Menurut Inggried Limbong, dkk [1] dalam jurnal ilmiah yang berjudul manajemen pengadaan material bangunan dengan menggunakan metode MRP (material requirement planning), memberi kesimpulan bahwa perencanaan kebutuhan material dalam suatu proyek dimaksudkan agar dalam pelaksanaan pekerjaan, penggunaan material menjadi efisien dan efektif sehingga tidak terjadi masalah akibat tidak tersedianya material pada saat dibutuhkan. MRP adalah suatu metode untuk menentukan bahan-bahan atau komponen-komponen apa yang harus dibuat atau dibeli, berapa jumlah yang dibutuhkan, dan kapan dibutuhkan. MRP terutama didasarkan atas keadaan persediaan material dan barang dalam proses serta jadwal induk produksi. Proses yang terdapat dalam MRP meliputi netting, lotting, offsetting, dan explosion.

Menurut Nyoman Yudha Astana [2] dalam jurnal ilmiah yang berjudul perencanaan persediaan bahan baku berdasarkan metode material requirement planning (MRP), memberi kesimpulan bahwa persediaan berpengaruh terhadap besarnya biaya operasi, sehingga kesalahan dalam mengelola persediaan akan mengurangi keuntungan.Perusahaan sering mengalami masalah persediaan, diantaranya persediaan terlalu banyak atau terjadi kekurangan. Kondisi tersebut dapat menimbulkan biaya yang besar. Oleh karena itu diperlukan manajemen persediaan untuk menganalisa tingkat persediaan optimum. Perencanaan kebutuhan material dilakukan dengan metode MRP penerapannya diawali melakukan peramalan jumlah permintaan atau produksi untuk waktu akan datang.

Penjelasan dari Tata Sutabri [5], teori sistem melahirkan konsep-konsep futuristik, antara lain yang terkenal adalah konsep sibernetika (cybernetics). Konsep atau bidang kajian ilmiah ini terutama berkaitan dengan upaya-upaya untuk menerapkan berbagai disiplin ilmu, yaitu ilmu perilaku, fisika, biologi dan teknik. Oleh karena itu sibernetika biasanya berkaitan dengan usahausaha otomasi tugas-tugas yang dilakukan oleh manusia, sehingga melahirkan studi-studi tentang robotika, kecerdasan buatan (artificial intelegence) dan lain sebagainya.

Menurut Tata Sutabri [5], model umum sebuah sistem terdiri dari input, proses dan output. Hal ini merupakan konsep sebuah sistem yang sangat sederhana mengingat sebuah sistem 
dapat mempunyai beberapa masukan dan keluaran sekaligus. Selain itu sebuah sistem juga memiliki karakteristik atau sifat-sifat tertentu, yang mencirikan bahwa hal tersebut bisa dikatakan sebagai suatu sistem.

Rusdah [6] menjelaskan dalam bukunya "Analisis Sistem Informasi”, informasi adalah data yang telah diklasifikasikan atau diolah atau diinterpresentasikan untuk digunakan dalam proses pengambilan keputusan. Pengertian informasi dari kedua penulis tersebut adalah data yang telah diolah dalam suatu bentuk yang lebih berguna untuk proses pengambilan keputusan.

Dijelaskan Jogyanto Hartono [7] informasi merupakan proses lebih lanjut dari data yang sudah memiliki nilai tambah. Istilah informasi seringkali tidak tepat pemakaiannya. Informasi dapat merujuk ke suatu data mentah, data tersusun, kapasitas sebuah saluran komunikasi dan lain sebagainya. Informasi ibarat darah yang mengalir di dalam tubuh suatu organisasi, sehingga peran dan kedudukan informasi ini sangat penting didalam suatu organisasi. Suatu sistem yang kekurangan informasi akan menjadi loyo, kerdil, dan akhirnya berakhir.

Hariningsih [8] menjelaskan bahwa fungsi utama informasi adalah untuk menambah pengetahuan dan mengurangi ketidakpastian pemakai informasi. Informasi yang disampaikan kepada pemakai mungkin merupakan hasil dari data yang dimasukkan kedalam pengolahan. Akan tetapi dalam kebanyakan pengambilan keputusan yang kompleks, informasi hanya dapat menambah kemungkinan kepastian atau mengurangi bermacam-macam pilihan. Informasi yang disediakan bagi pengambil keputusan memberikan suatu kemungkinan faktor resiko pada tingkattingkat pendapatan yang berbeda.

Dijelaskan oleh Arief Sugiono (2009) pengertian pengendalian adalah suatu informasi ekonomi yang akurat, maka manajemen perusahaan dapat mengontrol, menilai terhadap jalannya perusahaan. Pengendalian dapat mempertinggi kualitas, menurunkan biaya produksi, mempercepat laju produksi.

Dalam buku yang berjudul Analisis Sistem Informasi pengendalian bertujuan untuk menjamin kelancaran pelaksanaan pengelolaan dan produk-produk informasi, baik segi kualitas, kuantitas maupun ketepatan waktu. Pengendalian adalah keseluruhan kegiatan dalam bentuk mengamati, membina dan mengawasi pelaksanaan mekanisme pengelolaan sistem informasi, khususnya dalam fungsi-fungsi perencanaan informasi, transformasi, organisasi dan koordinasi.[9]

Raharjo [10] mendefinisikan persediaan adalah bahan atau barang yang disimpan yang akan digunakan untuk memenuhi tujuan tertentu, misalnya untuk digunakan dalam proses produksi ataupun untuk dijual kembali. Persediaan dapat berupa bahan mentah, bahan pembantu, barang dalam proses, barang jadi ataupun suku cadang. Bisa dikatakan tidak ada perusahaan yang beroperasi tanpa persediaan, meskipun sebenarnya persediaan hanyalah suatu sumber dana yang menganggur, karena sebelum persediaan digunakan berarti dana yang terikat didalamnya tidak dapat digunakan untuk keperluan yang lain. Begitu pentingnya persediaan ini sehingga para akuntan memasukannya dalam neraca sebagai salah satu pos aktiva lancar.

Dalam pengelolaan persediaan terdapat keputusan penting yang harus dilakukan oleh manajemen, yaitu berapa banyak jumlah barang atau item yang harus dipesan untuk setiap kali pengadaan persediaan, dan kapan pemesanan barang harus dilakukan.

Untuk memesan suatu barang sampai barang itu datang diperlukan jangka waktu yang bisa bervariasi dari beberapa jam sampai beberapa bulan. Perbedaan waktu antara saat memesan sampai saat barang datang dikenal dengan istilah waktu tenggang (lead time). Waktu tenggang sangat dipengaruhi oleh ketersediaan dari barang itu sendiri dan jarak lokasi antara pembeli dan pemasok berada. [11]

Menurut Tamodia [11] pengendalian adalah suatu informasi ekonomi yang akurat, maka manajemen perusahaan dapat mengontrol, menilai terhadap jalannya perusahaan. Pengendalian dapat mempertinggi kualitas, menurunkan biaya produksi, mempercepat laju produksi.

Pengertian pengendalian persediaan menurut Andreas [12] adalah serangkaian kebijakan pengendalian untuk menentukan tingkat persediaan yang harus dijaga, kapan pesanan untuk

JURNAL ILMIAH KOMPUTERISASI AKUNTANSI Vol. 14, No. 2, Desember $2021: 256-264$ 
menambah persediaan harus dilakukan dan berapa besar pesanan yang harus diadakan. Sistem ini menentukan dan menjamin tersedianya persediaan yang tepat dalam kuantitas dan waktu yang tepat

\section{Metode Penelitian}

Model penelitian secara umum dapat diartikan sebagai cara ilmiah untuk mendapatkan data dengan tujuan dan kegunaan tertentu. Setiap penelitian mempunyai tujuan dan kegunaan tertentu. Tujuan penelitian pengembangan sendiri berarti memperdalam dan memperluas pengetahuan yang telah ada.

Prosedur pengembangan menjelaskan langkah-langkah prosedural yang ditempuh oleh penulis sampai menghasilkan produk yang akan dikembangkan. Sesuai dengan model pengembangan yang digunakan, prosedur pengembangan yang ditempuh terdiri dari enam langkah, yaitu: (1) Analisis kebutuhan, (2) pangembangan produk (3) penyusunan prototipe bahan ajar, (4) uji coba, (5) revisi produk, dan (6) hasil akhir. Adapun prosedur pengembangan sistem informasi pengendalian persediaan BBM berbasis web yang dikembangkan dapatt digambarkan sebagai berikut :[13]

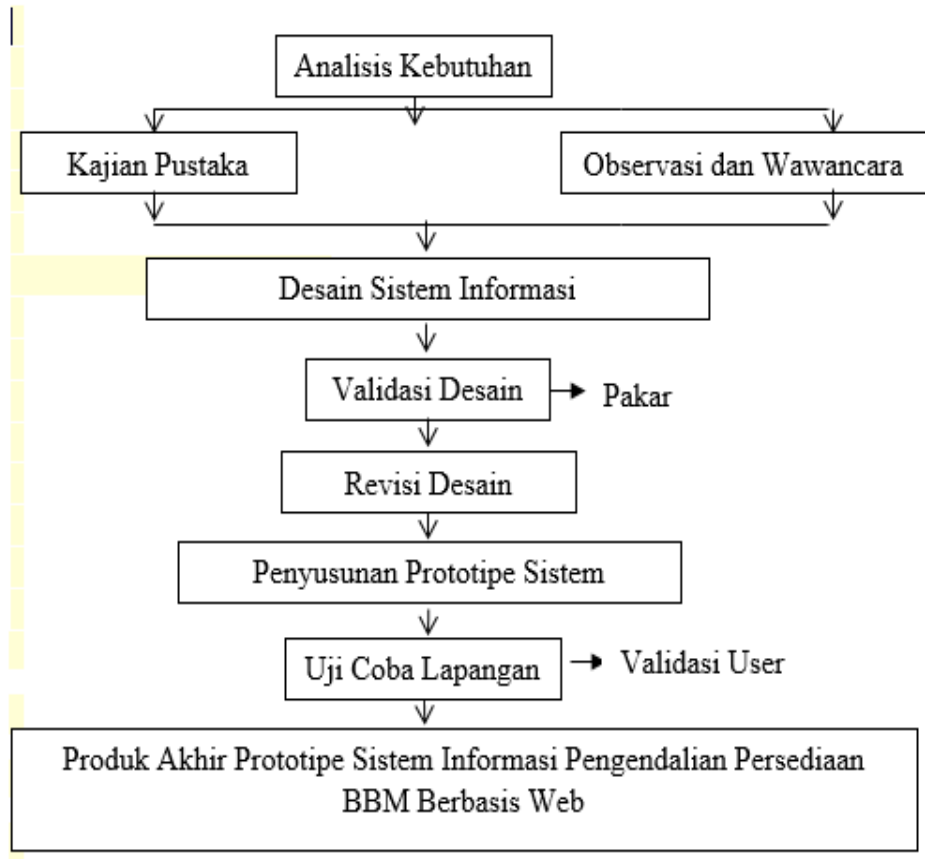

Gambar 1. Metode Pengembangan 


\section{Hasil dan Pembahasan}

1. Form Login Program

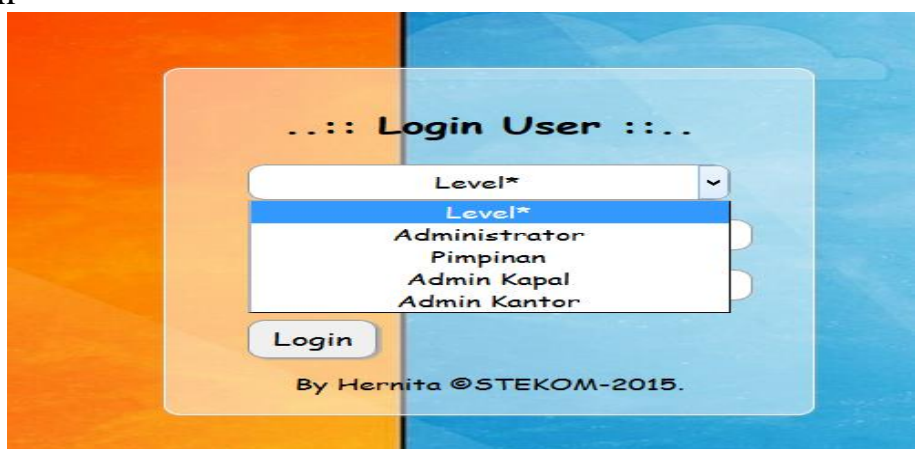

Gambar 2 Form Login Program

2. Menu Utama

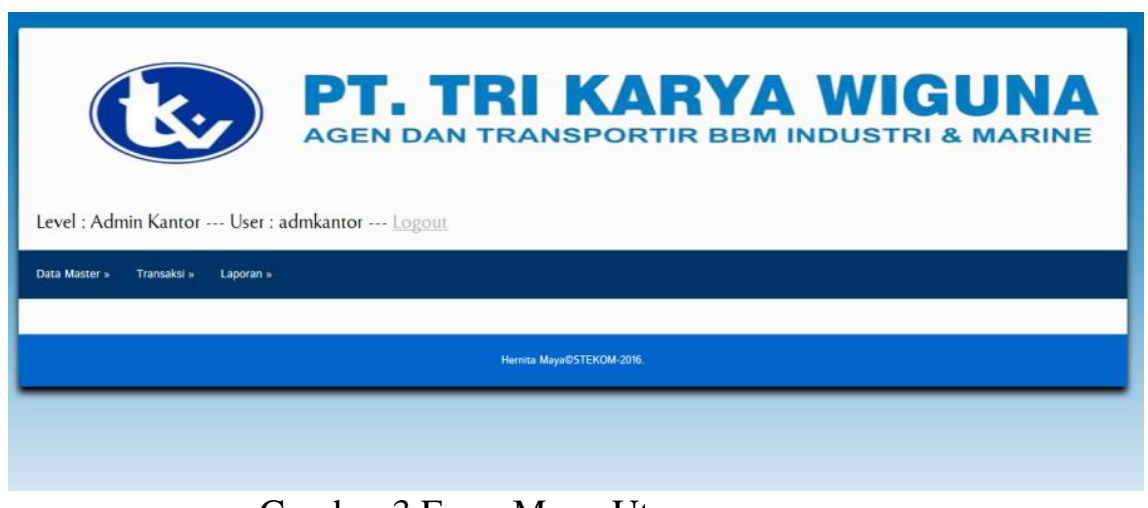

3. Form Input Data BBM

\section{Gambar 3 Form Menu Utama}

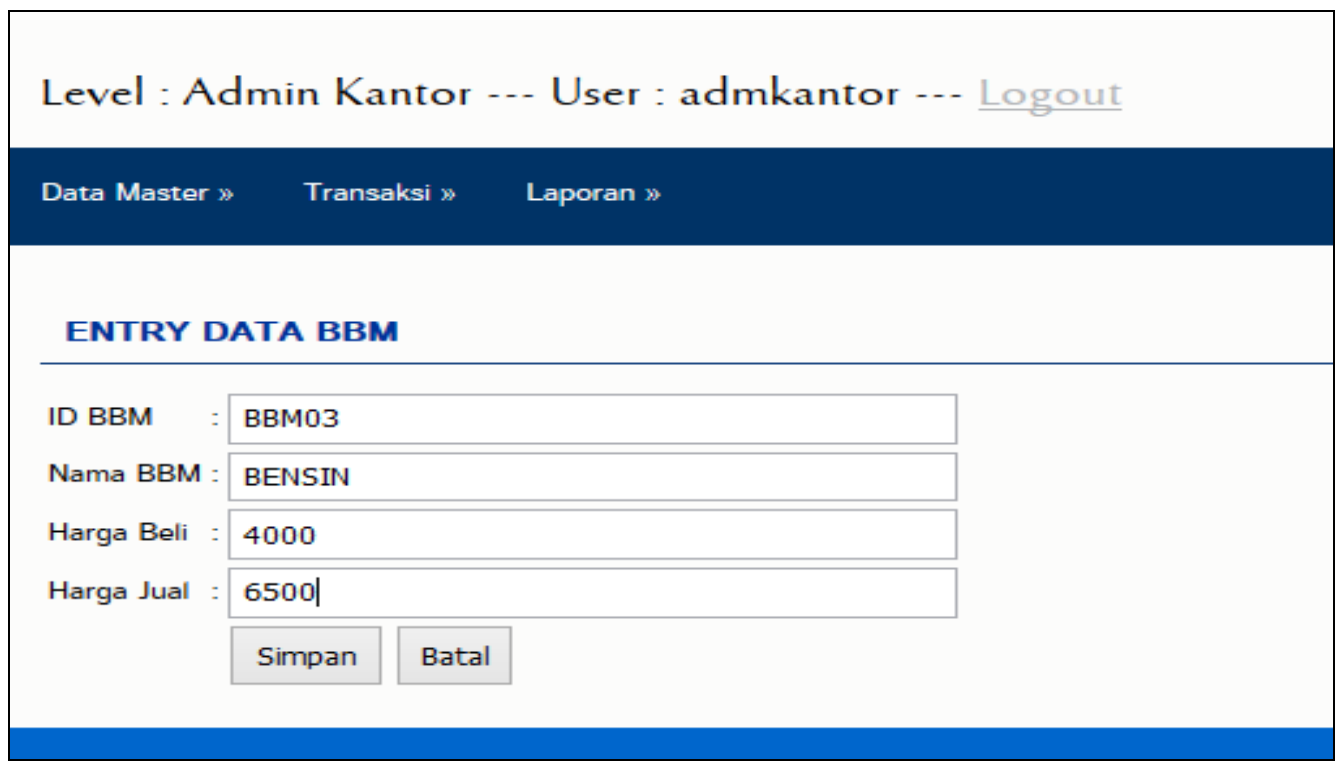

Gambar 4 Form Input Data BBM

Form Data BBM berfungsi untuk mengolah data-data BBM yang digunakan dalam proses produksi.

JURNAL ILMIAH KOMPUTERISASI AKUNTANSI Vol. 14, No. 2, Desember $2021: 256-264$ 
4. Form Input Data Pelanggan

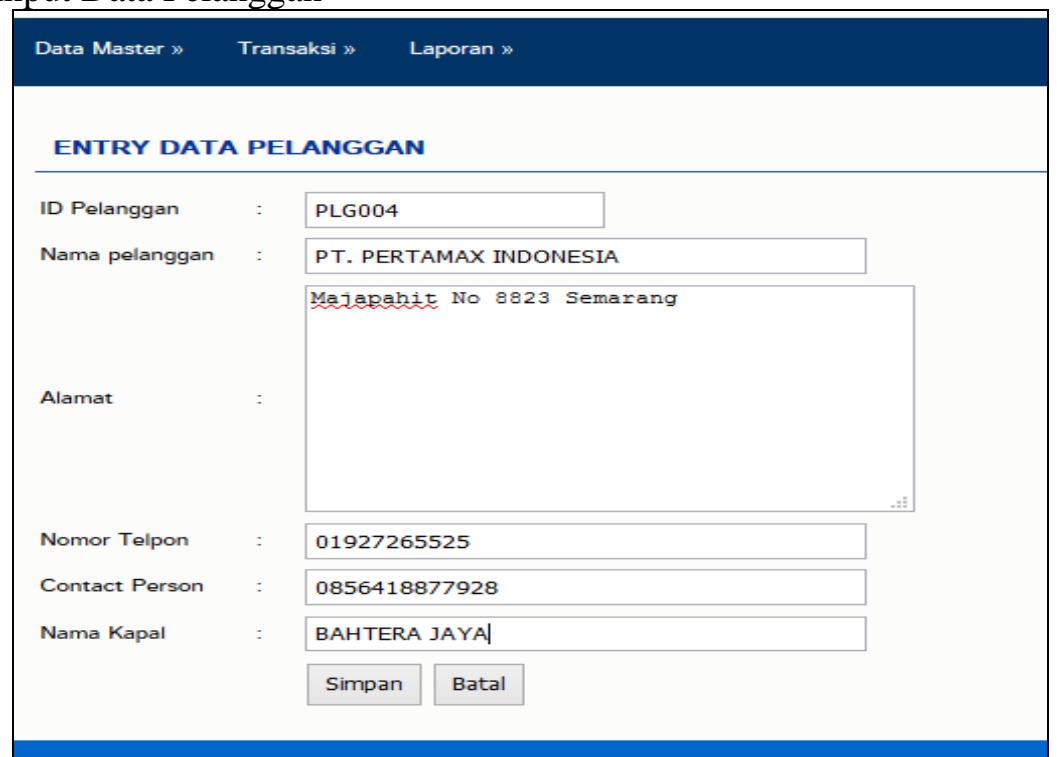

Gambar 5 Form Input Data Pelanggan

Form Input data pelanggan berfungsi untuk mengolah data-data pelanggan yang akan bekerjasama dengan perusahaan

5. Form Input Data Supplier

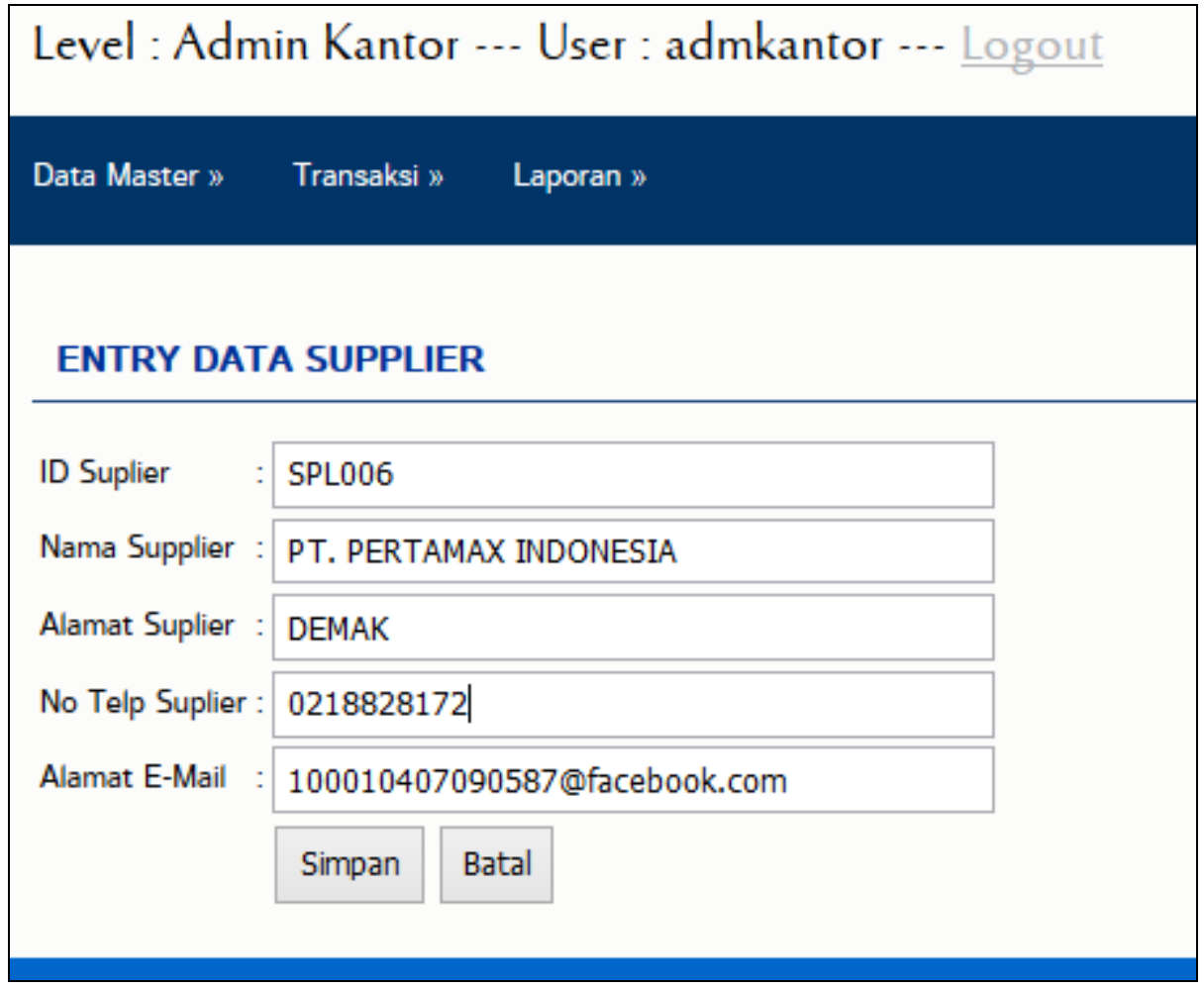

Gambar 6 Form Input Data Supplier 
Form Data Supplier berfungsi untuk mengolah data-data Supplier yang akan bekerjasama dengan perusahaan.

6. Form Input Data Kapal

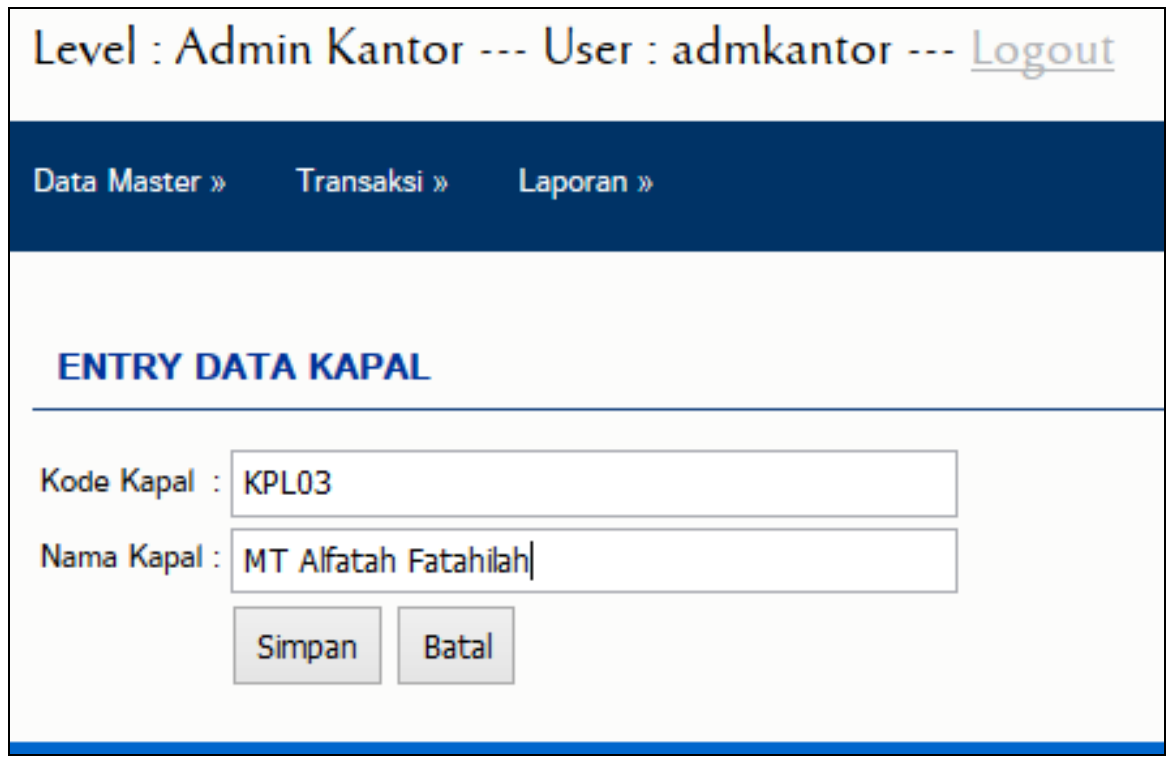

Gambar 7 Form Input Data Kapal

Form Data Kapal berfungsi untuk mengolah data-data Kapal yang akan bekerjasama dengan perusahaan.

7. Form Input Data Pengguna

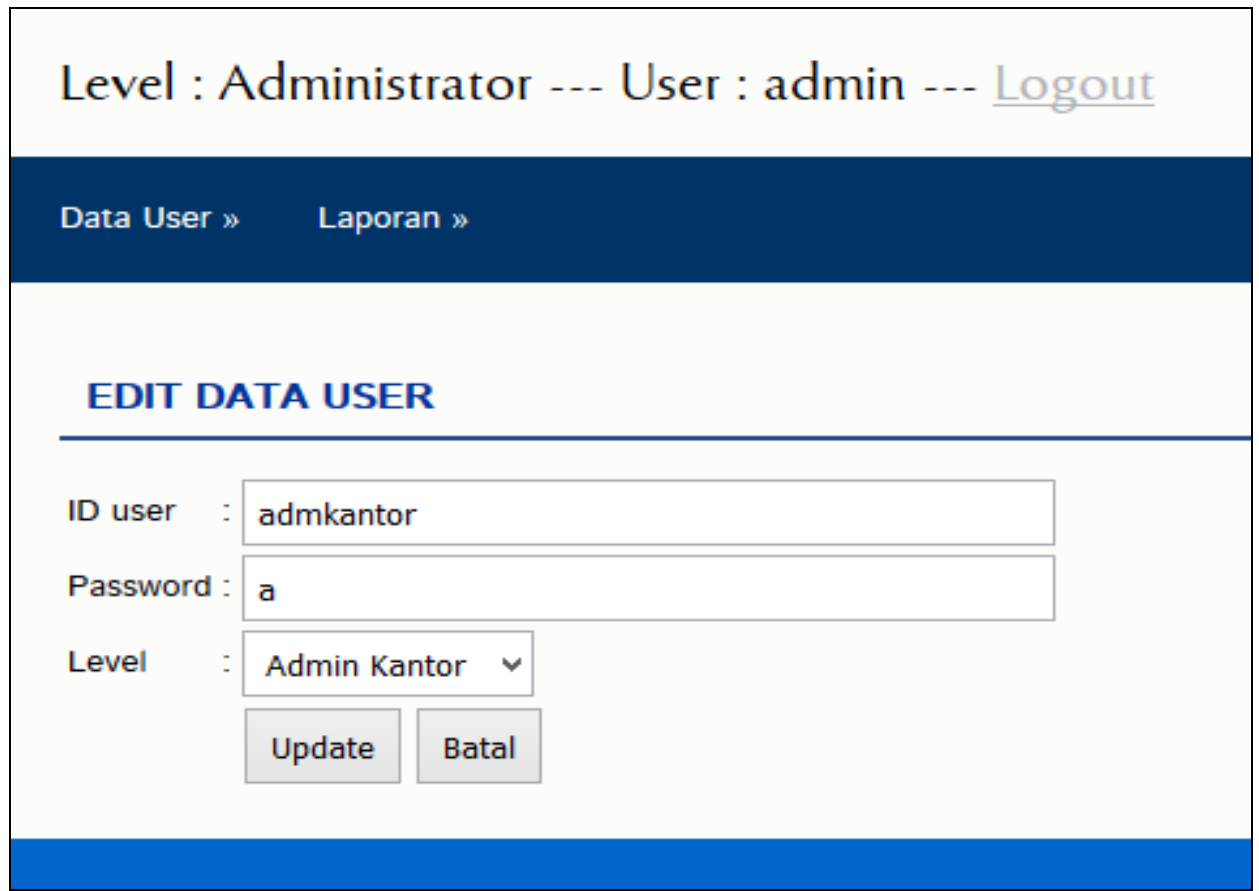

Gambar 8 Form Input Data Pengguna

Form Data Pengguna berfungsi untuk mengolah data-data pengguna yang akan menjalankan program aplikasi.

JURNAL ILMIAH KOMPUTERISASI AKUNTANSI Vol. 14, No. 2, Desember $2021: 256-264$ 


\section{Kesimpulan}

Sistem informasi persediaan bbm berbasis web yang dilakukan menggunakan metode Research and Development $(R \& D)$ dengan membuat rancangan sistem baru yang telah melalui pengujian desain oleh pakar dan juga ujicoba produk oleh user, maka produk sistem pengelolaan data persediaan BBM yang telah dikembangkan dinyatakan memenuhi tujuan yang diharapkan, sehingga dapat ditarik kesimpulan sebagai berikut:

1. Sistem Informasi terintegrasi yang didukung perangkat keras komputer dan aplikasi pengolah data yang handal, dapat menyajikan data dan informasi yang lebih cepat dan lebih akurat.

2. Sistem Informasi terkomputerasi berbasis Web data dapat diakses dimana saja secara online sehingga mempermudah Pimpinan memperoleh informasi yang berguna dalam pengambilan keputusan perusahaan.

3. Diterapkannya fungsi pengendalian yang sudah terprogram, misalnya untuk penggunaan data, hanya orang-orang tertentu saja yang dapat menggunakan dan mengakses.

4. Dapat meningkatkan daya saing perusahaan pada pihak luar terutama Pelanggan, supplier dan juga pesaing karena perusahaan sudah didukung oleh sistem Informasi yang profesional.

\section{Daftar Pustaka}

[1] Limbong, Inggried, dkk, 2013; jurnal: "Manajemen Pengadaan Material Bangunan dengan Menggunakan Metode MRP (Material Requirement Planning, studi kasus: Revitalisasi Gedung Kantor BPS Propinsi Sulawesi Utara", Sulawesi Utara: Universitas Sam Ratulangi, ISSN: 2337-6732 Jurnal Sipil Statik Vol.1 No.6, Mei 2013 (421-429).

[2] Astana, Nyoman Yudha, 2007; jurnal : "Perencanaan Persediaan Bahan Baku Berdasarkan Metode Material Requirement Planning di PT.Torsina Redikon”, Denpasar : Universitas Udayana, Jurnal Ilmiah Teknik Sipil, Vol. 11 No. 2 Juli 2007.

[3] Jogiyanto, Hartono, 2018; “Analisis dan Desain Sistem Informasi, Edisi VI'. Yogyakarta: ANDI.

[4] Mc.Leod, Raymond, Jr, 2011 “Management Information System”, Yogyakarta: Penerbit Andi

[5] Sutabri, Tata, 2012; “Konsep Sistem Informasi”, Yogyakarta: Andi.

[6] Rusdah, 2012; “Analisa Dan Rancangan Sistem Informasi Persediaan Obat", Jakarta: Universitas Budi Luhur.

[7] Mustakini, Jogiyanto Hartono, 2013; "Sistem Teknologi Informasi”. Yogyakarta: Andi.

[8] SP Hariningsih, 2012, "Teknologi Informasi”, Yogyakarta: Penerbit PT. Graha Ilmu

[9] Suseno Budi Praasetyo, 2011, "Analisis Efiseiensi distribusi Pemasaran Produk Dengan Metode Data Envelopment Analiysis, Teknik Industri-FTI-UPN V Jatim”, Jurnal Penelitian Ilmu Teknik Vol 8, No 2 Desember 2008:120-128.

[10] Rahardja, Untung, 2013; "Peningkatan kinerja distributed database melalui metode DMQ base leve”, vol. 4, Perguruan Tinggi Raharja, Tangerang, 2011, halaman 238. 
[11] Tamodia, Widya, 2017; "Evaluasi Penerapan Sistem Pengendalian Intern Untuk Persediaan Barang Dagangan Pada PT. Laris Manis Utama Cabang Manado", Manado: Universitas Sam Ratulangi.

[12] Andreas Arifianto, Januar Wahjudi, 2015, "Sistem Informasi Distribusi Barang Promosi PT Saka Farma” UNIVERSITAS MULTIMEDIA NUSANTARA TANGERANG". Ultimatics Vol.3 No 1, Juni 2011.

[13] Sugiyono. (2011), “Metode Penelitian Kuantitatif Kualitatif dan R\&D” Bandung. Alfabeta.

[14] Amin. Zaenal, dan Santoso. Yudi, 2012; "Pemodelan Sistem Informasi Persediaan Barang Pada PT. Nutech Pundi Arta". Jakarta: Universitas Budi Luhur. 